\title{
A study on investigating the impact of website features on online impulse buying behaviour
}

\section{Web sitesi özelliklerinin anlık çevrimiçi satın alma davranışı üzerindeki etkisinin araştırılmasına yönelik bir çalışma}

\author{
Sara Narimanfar ${ }^{1}$ \\ Peyman Ghafari Ashtiani ${ }^{2}$
}

\begin{abstract}
${ }^{1}$ Postgraduate of master of E-commerce Management, Islamic Azad University, Arak, Iran, sara.narimanfar@gmail.com ORCID: 0000-0002-4230-1819
\end{abstract}

2 Assoc. Prof., Islamic Azad University, Arak, Iran, p-Ghafari@iau-arak.ac.ir

ORCID: 0000-0003-1775-2287

\section{Corresponding Author:}

Sara Narimanfar,

Islamic Azad University, Arak, Iran, sara.narimanfar@gmail.com

\section{Submitted: 5/10/2021}

Revised: $12 / 11 / 2021$

Accepted: $22 / 11 / 2021$

Online Published: 25/12/2021

Citation: Narimanfar, S., \& Ghafari Ashtiani, P., A study on investigating the impact of website features on online impulse buying behaviour, tujom (2021) 6 (3):175-191, doi: https://doi.org/10.30685/tujom.v6i3.130

\begin{abstract}
E-commerce has led to many deliveries in business relationships specially used for online shopping. Given the growth of e-commerce to increase e-shopping, researchers can be investigated in this area in recent years. This paper aims to investigate the effect of website features on online impulse buying behaviour (OIBB). A questionnaire survey was conducted on the users of the Digi Kala website. They have made an impulsive online purchase at least once from the DigiKala website in Arak city, Iran. A relative stratified sampling technique was utilized for data collection. The data were analyzed statistically. The results show that: All research hypotheses have been confirmed. Among the research variables for the research's statistical sample, service quality and visual attraction affect online impulsive shopping behaviour.
\end{abstract}

Keywords: Impulse Buying, Impulsive Buying Behaviour, Consumer Behaviour, Website Quality, Service Quality, Web Service For E-Business, Digital Marketing, E-Commerce

Jel Codes: M15, M31, D1, M00

$\ddot{O} z$

E-ticaret, özellikle çevrimiçi alışveriş için kullanılan iş ilişkilerinde birçok teslimata yol açmıştır. Eticaretin e-alışverişi artırmak için büyümesi göz önüne alındığında, son yıllarda bu alanda araştırmacılar araştırılabilir. Bu makale, web sitesi özelliklerinin çevrimiçi anlık satın alma davranışı (OIBB) üzerindeki etkisini araştırmayı amaçlamaktadır. İran'ın Arak kentindeki DigiKala web sitesinden en az bir kez anlık çevrimiçi alışveriş yapan Digi Kala web sitesi kullanıcıları üzerinde bir anket çalışması yapılmıştır. Verilerin toplanmasında göreli tabakalı örnekleme tekniği kullanılmıştır. Veriler istatistiksel olarak analiz edildi. Sonuçlar şunları göstermektedir: Tüm araştırma hipotezleri doğrulanmıştır. Araştırmanın istatistiksel örneklemi için araştırma değişkenleri arasında hizmet kalitesi ve görsel çekicilik, çevrimiçi anlık alışveriş davranışını etkilemektedir.

Anahtar Kelimeler: Anında Satın Alma, Anlık Satın Alma Davranışı, Tüketici Davranışı, Web Sitesi Kalitesi, Hizmet Kalitesi, E-Ticaret Için Web Hizmeti, Dijital Pazarlama, E-Ticaret

IEL Kodları: M15, M31, D1, M00 


\section{Introduction}

With the increasing development of information technology globally and the replacement of electronic businesses with traditional business, providing a platform for customers who can make online purchases with ease and faster More than ever do, new needs have emerged. Consumers may make purchases online or physically in stores; in any case, they go through different steps in the purchase process. Before purchasing certain products, They plan to make a purchase. However, they may end up buying other products that they did not intend to buy. This unplanned purchase usually occurs in stores due to in-store advertising, which acts as a stimulus to remind or suggest to the consumer (Inman et al., 1990). Consumers make purchasing decisions because of the different factors in stores. While shopping in the physical world is often limited in time and geography, consumers in the digital world can purchase goods or services anytime and place, increasing the number of suddenly purchased goods.

What does this mean for online marketers? For example, what factors influence consumers' decision to buy something suddenly?

Providing an environment similar to the physical environment is challenging for online retailers because they can not transfer the facilities and experiences of the physical environment, such as seeing goods up close, creating the pleasure of shopping, and walking in the store from the real world to the online world. However, impulse purchases are still an essential source of profit for retailers' marketing activities. This business helps marketers create significant opportunities for sales profits (Beatty and Ferrell, 1998). Therefore, understanding the unpredictable behaviours of online consumers is essential for online marketers to increase sales opportunities and profitability. Due to the advantages of online shopping compared to traditional shopping in the modern world, more consumers have tended to shop online. Retailers in e-business are also trying to meet the needs of consumers as best as possible by designing attractive and appropriate websites. Due to the importance of this issue, extensive studies have identified factors that can affect customers' buying behaviour on the website (Poodar et al., 2009). Online shoppings need impulse buying to increase their profit and market share. In the meantime, the main problem is the lack of awareness of business owners and eshops who do not know how to increase the impulsive purchase of their stores, which should be familiar with these factors for their benefit. E-business website features are one factor that affects sudden online shopping (Haghighi, 2008).

Impulse consumer behaviour on e-commerce websites is an effective marketing strategy. It can be suggested to increase the impulse purchase volume of an online store and help consumers control their impulse buying behaviour. Therefore, according to today's need in e-commerce and studies, it can be said that the central issue of this research is that companies seek to gain a competitive advantage through electronic sales. Still, customers do not welcome online shopping as well as most organizations. E-business owners ignore their websites' quality and practical features. They ignore the impact these factors can have on the website and the trust and satisfaction of online consumers. Also, organizations do not have much information about website design to provide the best shopping experience for consumers (Song and Zahedi, 2005). The problem for these organizations is that instead of examining the factors influencing website design and using the experiences and opinions of their customers, they follow the example of Internet companies or non-Internet companies. One of the primary and vital problems today is to use several features to design a website without considering its impact on consumer behaviour, which can also be related to e-commerce. Business owners and designers of online stores and websites should be aware that different factors affect online and Internet users, but this effect can be other for consumers. It can be a reason to buy or not to buy them from the website. This lack of attention to the website features on customer satisfaction, trust, and attitude can be a fundamental problem with online shopping. In this way, if customers find the website ineffective, they will leave the website and never return to it. Identifying and examining the impact of website quality features on consumers' online impulse purchases is an essential issue in the information age. Therefore, this study describes the features of the electronic website that affect online impulse shopping behaviour. The overall purpose of this study is to investigate the effect of website features on impulse online shopping. 


\section{Literature review}

Impulse shopping is a unique consumer aspect. Retailers have also noticed the importance of this issue. For years, they have been trying to stimulate consumers to buy through the design and layout of unique stores, advertisements, and packaging. (Dholakia, 2000). In 1985, Rock and Hoch argued in their research that impulse purchase is a type of desire that makes the consumer more satisfied with their purchase. Usually, the consumer's perception of environmental stimuli stimulates his emotions and thus causes an impulsive purchase. (Rook and Hoch, 1985). Since the 1950s, impulsive purchases have been discussed in research on consumer behaviour. And today, impulsive purchases have become an essential source of income for business owners and retailers. And about 30 to 50 per cent of retail revenue can be attributed to sudden investments (Britsman and Sjolander, 2011). Chin Hung Liu 2017 in an article aimed at examining the impact of website design, word-of-mouth electronic advertising, perceived value, buying emotions in impact shopping using Net 7 , for example. A questionnaire was administered to users of Net 7 websites in North, Central, and South / East Taiwan and Offshore Island. The results show that: (1) Website design has a significant positive and direct effect on word-of-mouth electronic advertising, perceived value, and buying feelings. Likewise, word of mouth electronic, perceived value, and acknowledging feelings have a significant positive and direct impact on buying. Demographic variables of Net 7 users, such as academic achievement, current residence, and average monthly income, have a significant effect on web design, electronic word of mouth, perceived value, Buy emotions and buy unnecessarily. In 2007, Gregory Bressolls and François Durrieu proposed a conceptual framework to measure the effects of electronic service quality dimensions on customer satisfaction and sudden purchase motivation. The functional nature of customer purchase motivation is introduced as a modulator. This variable measures customers' tendency to trust or distrust purchasing incentives and their satisfaction with excessive purchases. The research used an online questionnaire for 4,109 customers of France's leading e-commerce website specializing in electronic and cultural goods. The results highlight the main dimensions of website quality and their direct impact on customer satisfaction and unnecessary purchase. In addition to this direct impact, the effect of website quality dimensions on purchasing motivation is also caused by customer satisfaction. Functional purchasing impulsivity moderates the impact of website quality dimensions on purchasing satisfaction and incentives and the impact of happiness on buying incentives.

In conclusion, the limitations and ways of research are discussed. Fogli and Guida (2015), in a study entitled A Practical Approach to Quality Assessment in the Use of Corporate Websites, have studied the relationship between the website and shareholders. To achieve their goal, they have examined the four concepts of initial quality, quality of use, internal quality, and final quality. In this paper, they are considering the effect of the main dimensions on the quality of the website, A new quality model that includes a set of main structures and features and sub-features have been presented. Ponte et al. (2015) have investigated the impact of trust and perceived value on online travel purchase intention. The sample population of this study was 451 people. Also, the research data were collected through a questionnaire and tested using the partial least squares method. The results show that the intention to buy online depends on the value perceived by customers and trust. Trust also depends on the security perceived by customers and understanding the quality of information. While customers understand security to invest in the website and the seller's reputation, privacy and security policies, website familiarity, third-party confidence seals, and a proper understanding of the person's seal Third-party, certification transfers depend on third parties, and privacy concerns the Internet.

\section{Usability}

Usability is the simplicity of learning to manage a computer. The simplicity of memorizing essential functions, the degree of error avoidance, the degree of site design efficiency, and the general satisfaction of the user with the level of site dominance, so we use the website as a good Defines how easy it is for the user to use the site(Nielsen, J.,1994). Websites with poor design inadvertently lose customers in the face of a highly reliable competitor. On the other hand, if a site is well organized, it will affect users' behaviour and interaction in the online environment. Ease of use is computer technology and e-commerce, which are very important for today's users. Ease of use is referred to as 
user-friendly. In e-commerce, ease of use includes easy access to information, functionality, guidance, and ordering. Depending on the past research and the stated reasons, it is proposed that;

$\mathrm{H}_{1}$ : The usability of the e-shop affects impulse buying.

\section{Information quality}

The quality of website information in the e-business environment means providing up-to-date, new, relevant, and understandable information. Such information will significantly impact consumers' attitudes, satisfaction, and purchase intentions. ( Delone, W. H., \& McLean, E. R, 2003). Some organizations only introduce themselves and provide general information about the organization. Accurate and relevant information on the website is essential. If the customer has trouble searching and getting the information they need from the site, it no longer matters how accurate the site's content is; they will most likely leave it. Explanations regarding the quality of information The second hypothesis of this research is that,

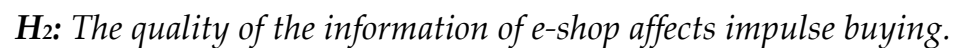

\section{Entertainment}

Another feature is the entertainment available on the website. In this case, the website is considered as the media. Some people think that television is the dominant medium, but websites will soon be the primary means of mass communication. In addition to providing information to users, organizations' websites should also be fun to consider. Entertainment includes animations, pictures, games and short films ( Yang et al., 2005). Therefore, another hypothesis of this research is that,

$H_{3}$ : The entertainment of the e-shop affects impulse buying.

\section{Security}

The foundation of e-commerce success is the issue of consumer security. It has gained widespread acceptance, so that one of the significant obstacles to the development of e-commerce is distrust (Turban et al., 2004). According to Chen's 2003 definition, virtual trust is a state of mind in which a person becomes vulnerable to trading electronically. The effect on e-trust is considered privacy, security of brand name and reputation, recommended advertisements, information, and having experience of activity and shopping through the Internet. Therefore, depending on the literature review and the reasons stated, The following hypothesis is proposed:

\section{H4: The security of the e-shop affects impulse buying.}

\section{Service quality}

Quality of service is customers' judgment and opinion about the superiority and efficiency of a service or service (Zeithaml, 2002). According to Zeithaml, an Electronic service is an Internet-based service that customers can provide services to themselves by interacting with the processes provided by the organization. The website should be responsible and reliable to help customers with fast service and accurate answers. The quality of electronic services can provide the advantage needed by organizations to compete in the electronic market and improve customer relations. According to Giffen in 2002, service quality; The mental comparison that customers make between the quality of services they want to receive and what they get. Service quality is recognized as an organizational asset and is also considered an essential factor in the company's marketing and financial performance. Given the importance of system quality on the e-commerce website, the fifth hypothesis is defined:

$H_{5:}$ The service quality of e-shop affects impulse buying.

\section{Customer satisfaction}

Customer satisfaction or dissatisfaction is defined in response to assessing the perceptual conflict between services provided and expectations; In this definition, customer satisfaction is a function of service quality expectations and performance (Tsai, W. H. S., \& Men, L. R., 2013). Regarding the definition of customer satisfaction, various opinions have been offered by marketing theorists. Lee and Turban consider electronic satisfaction as customer satisfaction according to their previous experience of visiting a website. Cutler defines customer satisfaction as the degree to which a company's actual performance meets customer expectations. According to Cutler, if the company's 
performance meets customer expectations, the customer will feel satisfied. Otherwise, he will feel dissatisfied. Due to lack of resources or limited resources, organizations must have a plan for every dollar he spends. Asking people who want to consume them is the best way to ensure business success. So we conclude that we need to look for ways to identify and measure customer satisfaction. Therefore, customer satisfaction has become the operational goal of many organizations. Therefore:

H6: The customer satisfaction of e-shop affects impulse buying.

\section{Responsiveness}

Responsiveness or customer support is one of the goals of the website. One of the critical points in the attractiveness of websites is to provide the possibility of two-way interaction with the customer (Ghahnavieh,2015). Therefore, another hypothesis of this research is that,

$H_{7}$ : The responsiveness of the e-shop affects impulse buying.

\section{Visual appeal}

The appearance and graphic design of the site is one of the practical features in the attitude and acceptance of users and their use of the website (McKinney et al.,2002). This factor is indicators such as attractiveness, graphic design, and multimedia capability, according to Huang in 2006.

$H_{8:}$ The visual appeal of the e-shop affects impulse buying.

\section{Research methodology}

\section{Sample and data collection}

This research has investigated the effect of website quality dimensions on impulse online shopping and the subject area in e-commerce. And because more impulsive purchases are standard for clothing, baby items, beauty products, and electronics such as cell phone accessories (according to research from the University of Michigan(2019)), this study also targets people who have purchased these items. The research area is in the city of Arak, which is the capital of Markazi province. The required information is collected by questionnaire, and the sample population is students from Arak Azad University. They have made a sudden online purchase from the Digi Kala website at least once.

The statistical sample is a subset of the statistical population that the researcher studies and studies to generalize the results to the statistical population. The scope of this research is Arak city, and the sample population is people who have made an online impulse purchase at least once from the Digikala website. Since students seem to use the Internet more and are more, they are familiar with online shopping. Therefore, Arak Azad University students are considered a community from which the sample is taken. Due to the large statistical population in this study and each faculty's diverse discipline, the population does not have relative homogeneity. Therefore, Relative stratified sampling in each faculty has been used to select the respondents to the questionnaires. The statistical sample size in this study was calculated using the Cochran sampling formula with an unlimited population size. Then the survey was distributed via the Internet and spread to the students in different units, and students were given a week to respond.

$$
n=\frac{N Z^{2} \alpha / 2 \times P(1-P)}{\varepsilon^{2}(N-1)+Z^{2} \alpha / 2 P(1-P)}
$$

Formula (3-1):

: N: Sample size

: P: Success rate in the statistical community

1-P: failure rate in the statistical community

e: Accuracy of sample estimation error

$Z$ : The standardized value of the normal distribution, which is 1.96 with a $95 \%$ confidence level.

In this research, the level of sampling error is $5 \%$, the level of reliability is $95 \%$, and the degree of variability in the studied features is $50 \%$. 
By placing the above values in the above equation, the minimum required samples was calculated to be 384. Then, the necessary number of faculties is obtained from the sample size using the following formula. Finally, the results are given in Table 1.

S: Number of college students

$\mathrm{N}$ : Number of total university students $\mathrm{N}=11000$

$\mathrm{Y}$ : The number of each faculty from the sample size $\mathrm{Y}=\mathrm{S} / \mathrm{N} * 384$

Table 1: Number of each faculty of sample size

\begin{tabular}{|l|l|l|}
\hline \multicolumn{1}{|c|}{ University faculties } & number of students & Y \\
\hline Medical Sciences & 2364 & 80.64 \\
\hline Agriculture and Natural Resources & 120 & 38.4 \\
\hline Humanities & 3133 & 107.52 \\
\hline Engineering & 2750 & 96 \\
\hline Management & 2000 & 69.12 \\
\hline Science & 633 & 19.2 \\
\hline Total & $\mathbf{1 1 0 0 0}$ & $\mathbf{4 1 0 8 8}$ \\
\hline
\end{tabular}

Therefore, 411 questionnaires were distributed among the distributed questionnaires, and according to the supervisor, 384 valid questionnaires were collected and analyzed. To collect information on the theoretical foundations and literature of the subject research, we used library resources, including articles, review of dissertations and research related to the subject, Internet search, and Persian and Latin books. Also, in this study, data were collected by questionnaire and field research. Therefore, it can be said that the questionnaire is the most common method used for data collection and also the most effective way for collecting experimental data from large samples. In this research, standard questionnaire questions that are approved have been used. In addition, there are closed-ended questions in the questionnaire that test the research hypotheses. The questions are designed on a 5point Likert scale (strongly disagree to agree strongly).

\section{Reliability and validity}

In this study, to increase the validity of the questionnaire, the following items were used:

The literature questionnaire and the questions used in similar researches were studied.

In order to determine the validity, a questionnaire was provided to the supervisor. Then, after applying his opinion and performing the necessary reforms, the final form of the questionnaire was developed and used.

Cronbach's alpha is one of the most common methods of measuring reliability, which is calculated using SPSS software and is obtained according to Equation below which:

$$
r a=\frac{k}{k-1}\left(1-\frac{\varepsilon s^{2} k}{s^{2}}\right)
$$

K: Number of questions

$s^{2} k$ : The variance of all subjects' answers to question $\mathrm{k}$

$s^{2}$ : The variance is the sum of the scores of each respondentCronbach's Alpha coefficient is a number between zero and 1. If the coefficient obtained from the mentioned relation is more significant than 0.7, the questionnaire has reliability. Thus, 31 questions were distributed among 30 people, and after collecting the answers, the alpha coefficient was calculated. As shown in Table 2, Cronbach's alpha of this questionnaire had sufficient reliability $(\alpha>0.7)$. 
tujom (2021) 6 (3):175-191

Table 2: Evaluation of the reliability of the questionnaire using Cronbach's alpha

\begin{tabular}{|c|c|c|}
\hline Cronbach's alpha & Number of items & Variable \\
\hline .842 & 5 & v1 \\
\hline .736 & 4 & v2 \\
\hline .924 & 3 & v3 \\
\hline .707 & 3 & v4 \\
\hline 713. & 3 & v5 \\
\hline 773. & 3 & v6 \\
\hline 831. & 3 & v7 \\
\hline 781. & 4 & v8 \\
\hline 788. & 3 & v9 \\
\hline
\end{tabular}

Two methods of descriptive statistics and inferential statistics are used to analyze the data:

A) Descriptive statistics: Descriptive statistics consist of many tables and graphs. In this type of analysis, the researcher summarizes and classifies the collected data using descriptive statistics indicators.

B) Inferential statistics: Model analysis is performed using the structural equation method and LISREL software.

Table 3 demonstrates the demographic breakdown of the respondents. Again, most of the sample was female $(64.06 \%)$, relatively young. Also, the piece seemed to be a highly educated group, with the majority of the respondents holding bachelor's degrees and master's degrees.

Table 3: Demographic characteristics

\begin{tabular}{|l|l|}
\hline Gender & Per cent \\
Fale & 35.94 \\
Female & 64.06 \\
\hline Age & Per cent \\
26-35 than 25 & 13.54 \\
36-45 & 35.94 \\
46-55 & 35.42 \\
Upper than 55 & 10.16 \\
\hline Education & 4.95 \\
Diploma & Per cent \\
Associate Degree & 9.64 \\
Bachelor & 52.60 \\
Master and upper & 37.76 \\
\hline
\end{tabular}

\section{Results}

The overall fit indices of the model show a favourable situation, as shown in Table 4. The Chi-square value of the model indicates that the difference between the observed and reproduced covariance 
matrices cannot be considered statistically significant. Therefore, the RMSEA fit index and its confidence interval of 0.90 are in the acceptable range. This index, which is calculated by combining the properties of absolute indices, economic indices (emphasis on the degree of freedom), and sample size, is one of the most critical models of fit indices.

Table 4: Table of names and values of appropriate indicators

\begin{tabular}{|l|l|l|}
\hline \multicolumn{1}{|c|}{ Fit index name } & Acceptable optimal level & Fit index value \\
\hline Df & -- & 398 \\
\hline Chi-Square & -- & 943.04 \\
\hline$\chi^{2} / d f$ & Less than 0.05 & 2.369 \\
\hline RMSEA & & \\
\hline CFI & Less than 0.01 & 0.060 \\
\hline IFI & More than 0.90 & 0.96 \\
\hline NNFI & More than 0.90 & 0.96 \\
\hline & More than 0.90 & 0.95 \\
\hline
\end{tabular}

\section{Testing hypotheses}

The hypotheses of the present study have been tested using structural equation modelling. Structural equations are a suitable statistical technique that tests causal models with a linear equation system based on hypotheses about causal relationships between variables. In this way, structural equation modelling examines the theoretical relationships between given and assumed structural conditions and makes causal estimation between latent (unobserved) variables and relationships between measured (observed) variables possible. It is generally accepted that multivariate regression methods resist violating the normal distribution of error sentences. The central limit theorem and the theory of large samples also allow the critical ratios (t-values) of the LISREL to approach the multivariate normal distribution.

In the present study, after drawing the model based on the data, the size of the model parameters has been obtained using LISREL software. Therefore, hypotheses have been tested using gamma coefficients $(\gamma)$ using a t-test. As mentioned earlier, the measurement model defines the relationships between the measured and latent variables for which an approximate estimate is used. In the desired measurement model, the met values $\gamma$ and the t-test values for them are shown in Figures 1 and 2, respectively. LISREL calculates a value of $t$ for each free (measured) parameter. This test shows which parameters can be removed from the model without increasing the chi-square value. Ideally, these values should be less than 1.96 to be considered meaningless. However, in the present analysis, all parameters have $t$ values greater than 1.96, which indicates the necessity of these parameters for the model. 


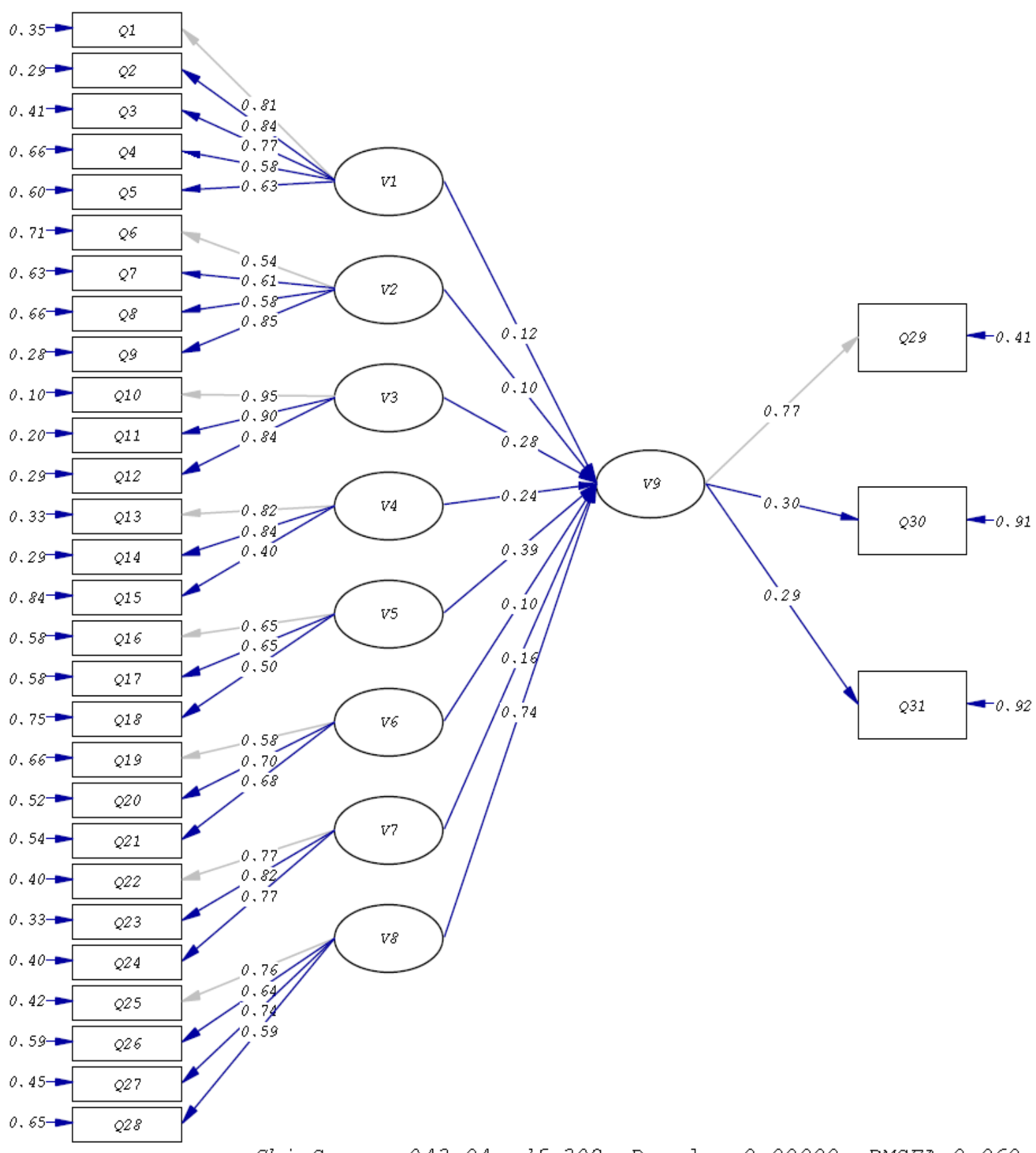

Chi-Square $=943.04, d f=398, \quad P$-value $=0.00000, \quad$ RMSEA $=0.060$

Fig 1: Standardized coefficients of the structural model and measurement 


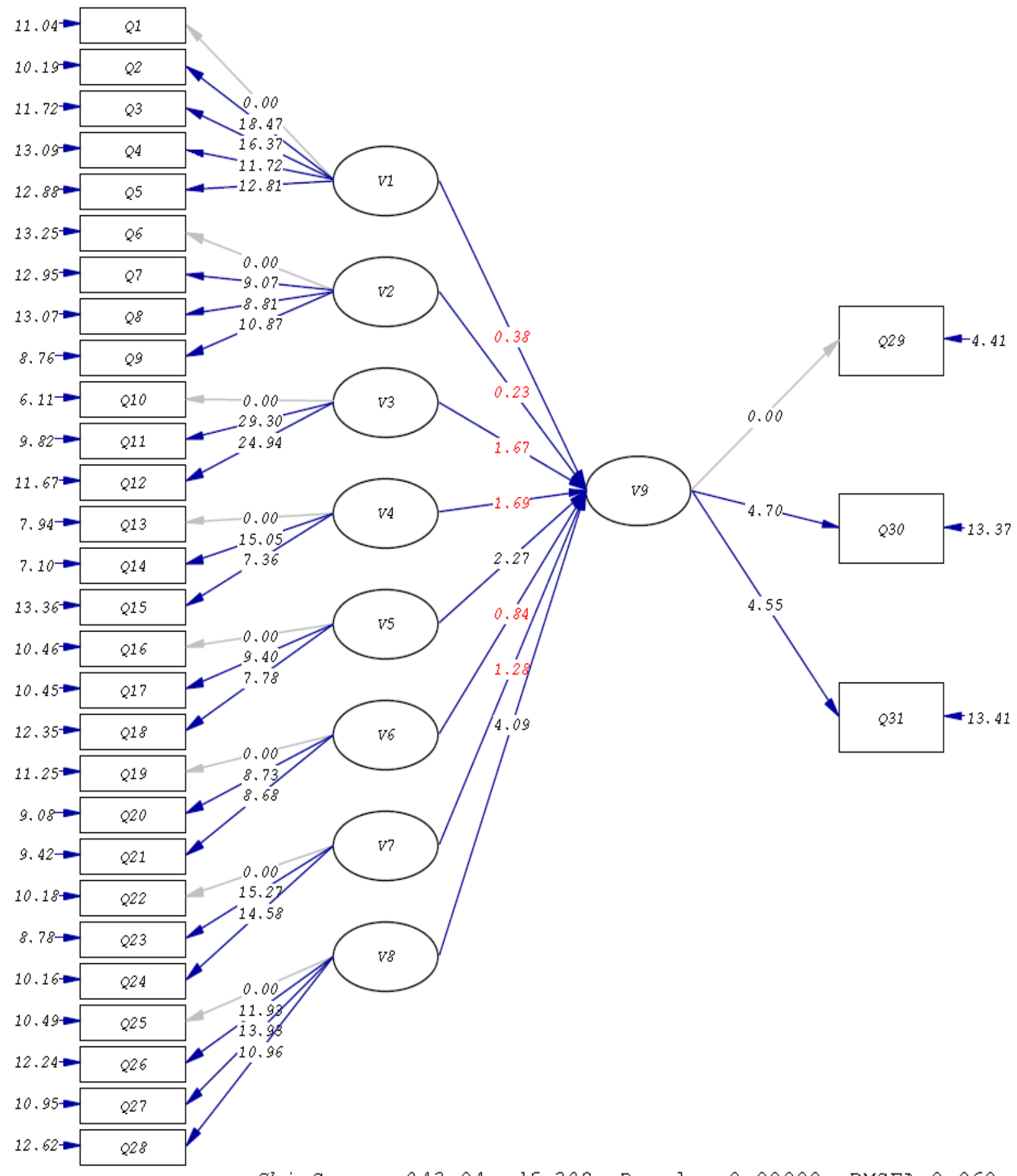

Chi-Square=943.04, df=398, P-value=0.00000, RMSEA $=0.060$

Fig 2: T-statistic for model coefficients

The results of the above are summarized in Table 5. 
tujom (2021) 6 (3):175-191

Table. 5. Regression weights - Factor loads of the research model

\begin{tabular}{|c|c|c|c|c|}
\hline Predictive variables & & $\begin{array}{l}\text { Predictable } \\
\text { variables }\end{array}$ & Standardized values & T statistics \\
\hline Usability & $\rightarrow$ & \multirow{8}{*}{$\begin{array}{l}\text { Impulse online } \\
\text { shopping }\end{array}$} & $0 / 12$ & $0 / 38$ \\
\hline Information quality & $\rightarrow$ & & $0 / 10$ & $0 / 23$ \\
\hline Entertainment & $\rightarrow$ & & $0 / 28$ & $1 / 67$ \\
\hline Security & $\rightarrow$ & & $0 / 24$ & $1 / 69$ \\
\hline Service quality & $\rightarrow$ & & $0 / 39$ & $2 / 27$ \\
\hline Customer satisfaction & $\rightarrow$ & & $0 / 10$ & $0 / 84$ \\
\hline Responsiveness & $\rightarrow$ & & $0 / 16$ & $1 / 28$ \\
\hline Visual appeal & $\rightarrow$ & & $0 / 74$ & $4 / 09$ \\
\hline Usability & $\rightarrow$ & Q1 & $0 / 81$ & -- \\
\hline Usability & $\rightarrow$ & Q2 & $0 / 84$ & $18 / 47$ \\
\hline Usability & $\rightarrow$ & Q3 & $0 / 77$ & $16 / 37$ \\
\hline Usability & $\rightarrow$ & Q4 & $0 / 58$ & $11 / 72$ \\
\hline Usability & $\rightarrow$ & Q5 & $0 / 63$ & $12 / 81$ \\
\hline Information quality & $\rightarrow$ & Q6 & $0 / 54$ & -- \\
\hline Information quality & $\rightarrow$ & Q7 & $0 / 61$ & 9/07 \\
\hline Information quality & $\rightarrow$ & Q8 & $0 / 58$ & $8 / 81$ \\
\hline Information quality & $\rightarrow$ & Q9 & $0 / 85$ & $10 / 87$ \\
\hline Entertainment & $\rightarrow$ & Q10 & $0 / 95$ & -- \\
\hline Entertainment & $\rightarrow$ & Q11 & $0 / 90$ & $29 / 30$ \\
\hline Entertainment & $\rightarrow$ & Q12 & $0 / 84$ & $24 / 94$ \\
\hline Security & $\rightarrow$ & Q13 & $0 / 82$ & -- \\
\hline Security & $\rightarrow$ & Q14 & $0 / 84$ & $15 / 05$ \\
\hline Security & $\rightarrow$ & Q15 & $0 / 40$ & $6 / 36$ \\
\hline Service quality & $\rightarrow$ & Q16 & $0 / 65$ & -- \\
\hline Service quality & $\rightarrow$ & Q17 & $0 / 65$ & $9 / 40$ \\
\hline Service quality & $\rightarrow$ & Q18 & $0 / 50$ & $7 / 78$ \\
\hline Customer satisfaction & $\rightarrow$ & Q19 & $0 / 58$ & -- \\
\hline Customer satisfaction & $\rightarrow$ & Q20 & $0 / 70$ & $8 / 73$ \\
\hline Customer satisfaction & $\rightarrow$ & Q21 & $0 / 68$ & $8 / 68$ \\
\hline Responsiveness & $\rightarrow$ & Q22 & $0 / 77$ & -- \\
\hline Responsiveness & $\rightarrow$ & Q23 & $0 / 82$ & $15 / 27$ \\
\hline Responsiveness & $\rightarrow$ & Q24 & $0 / 77$ & $14 / 58$ \\
\hline Visual appeal & $\rightarrow$ & Q25 & $0 / 76$ & -- \\
\hline Visual appeal & $\rightarrow$ & Q26 & $0 / 64$ & $11 / 93$ \\
\hline Visual appeal & $\rightarrow$ & Q27 & $0 / 74$ & $13 / 93$ \\
\hline Visual appeal & $\rightarrow$ & Q28 & $0 / 59$ & $10 / 96$ \\
\hline $\begin{array}{l}\text { Impulse online } \\
\text { shopping }\end{array}$ & $\rightarrow$ & Q29 & $0 / 77$ & -- \\
\hline $\begin{array}{l}\text { Impulse online } \\
\text { shopping }\end{array}$ & $\rightarrow$ & Q30 & $0 / 30$ & $4 / 70$ \\
\hline $\begin{array}{l}\text { Impulse online } \\
\text { shopping }\end{array}$ & $\rightarrow$ & Q31 & $0 / 29$ & $4 / 55$ \\
\hline
\end{tabular}

Table 6 below illustrates hypotheses testing results:

Table 6: Testing hypotheses

\begin{tabular}{|c|c|c|c|}
\hline Result & Value $\mathbf{t}$ & Path coefficient & Hypothesis \\
\hline Accept H0 & $0 / 38$ & $0 / 12$ & Usability \\
\hline Accept H0 & $0 / 23$ & $0 / 10$ & Information quality \\
\hline Accept H0 & $1 / 67$ & $0 / 28$ & Entertainment \\
\hline Accept H0 & $1 / 69$ & $0 / 24$ & Security \\
\hline Reject H0 & $2 / 27$ & $0 / 39$ & Service quality \\
\hline Accept H0 & $0 / 84$ & $0 / 10$ & Customer satisfaction \\
\hline Accept H0 & $1 / 28$ & $0 / 16$ & Responsiveness \\
\hline Reject H0 & $4 / 09$ & $0 / 74$ & Visual appeal \\
\hline
\end{tabular}

\section{Descriptive statistics results}

$35.94 \%$ of the subjects were male, and $64.06 \%$ were female. In fact, according to the data shown, it can be inferred that the majority of online shopping customers in the impulsive purchase in online stores are female consumers. 
The results regarding the age status indicate that the lowest age was 55 years and the highest generation was 26 to 35 years. Therefore, according to the effects of descriptive statistics on the age of people, it can be said that the relatively young, strong, and motivated age are in favour of impulsive purchases from online stores.

\section{Results of research hypotheses}

Hypothesis 1. The usability of the e-shop affects impulse purchases. The observations showed that this hypothesis with a value of $t$ equal to 0.38 at an error level of 0.05 with a confidence of 0.95 is not significant and is not confirmed. As mentioned earlier, usability is the ease of memorizing essential functions, ease of learning, the ability to manage a computer, degree of error avoidance, degree of site design efficiency, and general user satisfaction with mastery of the site. Ease of use means how easily a consumer can use the system and how much the system is understandable and learnable for him, which is crucial in deciding to buy online. According to a 2007 study by Grégory Bressolles François Durrieu , this hypothesis has been confirmed and has an impact on sudden purchases(Grégory Bressolles François Durrieu,2007). Also (Moe and Fader, 2004), in their research on ease of use, stated that whenever consumers have a sense of desire and motivation to buy, they can buy, and it is simply the use of the website or ease of use that Can easily find the product they are eager to buy. And this is a feature that increases impulsive purchases.

In this study, criteria such as ease of use, clear and understandable interaction with the website, ease of search to achieve usability in the questionnaire were asked. And considering the rejection of this hypothesis, it seems that the search feature, which is one of the essential features of e-commerce websites, is not a strong incentive for impulsive purchases for the statistical community of this study, which is the users of the DigiKala website. The reason for rejecting this hypothesis in this study may be related to the many categories of Digikala goods. By entering the desired class, find and select related products. Finding specific products such as mobile phones, TVs, and refrigerators is not tricky. Still, these products are not in the category of products usually bought in an impulsive purchase. Some goods are not easily found and may be seen only by searching.

Hypothesis 2. The quality of e-shop information affects the purchase. With the observations made in the research, it was found that this hypothesis with a value of $t$ equal to 0.23 at the error level of 0.05 with a confidence of 0.95 is not significant and is not confirmed. According to Childers' research in 2001, improving website content can make online shoppers happier and affect their shopping feelings. According to Gajendra Sharma Wang Lijuan in 2015, this hypothesis has been confirmed, and impacts impulse purchases. Therefore, this feature can lead to impulse purchases by affecting consumers' emotions. The result of this research may be that product descriptions and reviews are far from the existing reality in the opinion of users. Also, in the review section, Digi Kala focuses on praising the relevant product for selling it to the customer, and only occasionally, some minor flaws are mentioned. In an impulsive purchase, the consumer acts quickly and does not compare or consider other selections, so the information on the same site should be wide enough to cover all the product's features.

Hypothesis 3. The entertainment aspect of the e-shop affects the purchaser. The observations showed that this hypothesis with a value of $t$ equal to 1.67 at the error level of 0.05 with a confidence of 0.95 is not significant and is not confirmed. According to research (Cox et al., 2005), impulsive purchases are described through reduced information processing and cognitive (perceptual) reactions. They can often be based on a product's ability to evoke excitement or happiness. Various motivations, such as bargaining, socializing, or pleasure, can lead to shopping. And also, according to research (Floh and Madlberger, 2013), people who enjoy their shopping experiences and their shopping activities to Leisure titles are often prone to impulsive buying behaviour. This research questionnaire examined enjoyment, feeling excited, and happiness. And the reason for the lack of entertainment on the sudden purchase of users may be that the website in question did not meet the expectations of users about these criteria, and the use and spending time on the website does not cause emotions such as excitement.

Hypothesis 4. The security of the e-shop affects the purchase. The observations showed that this hypothesis with a value of $t$ equal to 1.69 at the error level of 0.05 with a confidence of 0.95 is not significant and is not confirmed. In the study, Pont et al. Examined the role of security and trust in 
online shopping. According to a 2007 study by Grégory Bressolles François Durrieu, this hypothesis has been confirmed and impacts impulsive purchases. According to research (Corbitt et al., 2003), security or trust is defined as a dimension of business relations that determines the level at which each party feels it can trust the integrity of the promise made by the other party. Every e-shopper usually perceives a higher risk than a typical shopping environment due to virtual identity, distance, and nonregulation. Therefore, trust is a prerequisite for e-commerce participation for consumers. According to the results, it can be argued that with the security of consumers by the website, they will return to the site and the possibility of an impulse purchase from the site increases. Therefore, security affects consumer behaviour and decisions in online shopping, so checking the security of e-commerce websites and providing a safe environment for consumers is very important. However, considering the rejection of this hypothesis in this study, it seems that Digi Kala has not been able to gain the trust of the audience of this research about website security. Another reason could be consumers' lack of technological awareness about the definition of security.

Hypothesis 5. The quality of e-shop service affects the purchase. The observations showed that this hypothesis with a value of $t$ equal to 1.27 at the error level of 0.05 with a confidence of 0.95 is significant and is confirmed. Research over the past two decades has shown that service quality affects consumer decisions and attitudes in the traditional environment. Still, recently these findings have also been used in e-commerce. For example, service quality measures to evaluate the quality of virtual community websites and research (Liu and Arnett, 2000) on e-commerce channel satisfaction have been the determinants of website success. This means that quality service requires service and the seller's ongoing commitment to improving processes and training employees to improve service. According to Gajendra Sharma Wang Lijuan's research in 2015, this hypothesis has been confirmed and impacts impulsive purchases. According to the results, it can be argued that Digikala meets the needs of customers, so the impulsive purchase increases on this site. One of the good features of this site is that it is possible to determine the exact time and day of sending the product. Also, if the product has any problems, the product referral service can be used immediately.

Due to this issue, it is suggested:

- Business owners to increase website service quality by providing a warranty, guarantee, and appropriate support. Also, to respond to potential problems of consumers at any time, thereby assuring customers that their products are healthy and defective, the site is responsive. Considering that products and services have support services, buyers make purchases with more confidence and feel satisfied at the time of sale.

- Business owners can also gain the trust and attention of customers by providing quality products at reasonable prices, not delaying the time of sending the requested goods, following up and handling the complaints of their customers, and returning defective products.

- Retailers can also increase satisfaction with the site by replacing the damaged products and aftersales service.

Hypothesis 6. E-shop customer satisfaction affects purchasing. Observations showed that this hypothesis with a value of $t$ equal to 0.84 at the error level of 0.05 with a confidence of 0.95 is not significant and is not confirmed. However, according to a study by Grégory Bressolles François Durrieu in 2007, this hypothesis has been confirmed and impacts impulsive purchases. According to research results (Haghighi, 2008), if online shoppers and consumers are satisfied with a website, they will be inclined in the future. To buy from that website again and consumers can increase the users through word of mouth ads. Therefore, satisfaction is an essential factor that determines whether consumers return to the website and buy from it or not. Considering that this research was done during the coronavirus epidemic and due to the rejection of this hypothesis, it seems that recently DigiKala has not been able to meet the needs of customers by providing a good shopping experience for them and consumers satisfaction.

Hypothesis 7. The responsiveness of the e-shop affects impulse purchases. Observations showed that this hypothesis with a value of t equal to 1.28 at the error level of 0.05 with a confidence of 0.95 is not significant and is not confirmed. Since the impulse purchase is made quickly, the website should provide immediate service to the user. According to research (Amiri, 2015), interaction is essential for 
any online seller. If customers do not receive sufficient and appropriate support for any problems or questions they face, their confidence will decrease. Therefore, prompt response and effective communication are essential for online businesses to be customer-oriented and act courteously. Since some of Digi Kala's products are not available in the company's warehouse, Digi Kala plays the role of sales intermediary. This time can be increased to four or even five days, which is usually a weakness for immediate purchase. Therefore, according to the results, it can be argued that the responsiveness of the DJ Kala website does not positively affect the impulse purchase of consumers.

Hypothesis 8. The visual appeal of an e-shop affects impulse purchases. With a value of t equal to 4.09 at the error level of 0.05 with a confidence of 0.95 , the desired statistic is significant and is confirmed. Website design has a substantial impact on e-business. Users and online shoppers tend to buy from websites with a more attractive and appropriate appearance. The proper formation of the website and being more attractive prevents users from getting tired and allows users to spend time on those sites. It can also be said that the results of this study are consistent with the results (Toufaily et al., 2013) and also (Yaghoubi, 2015). Website visualization can affect user satisfaction and increase consumers' desire to buy. Also, the creativity of the website creates the mental judgment of the consumer or the user, so the website can better meet their expectations with creative and new presentations. Also, the DJ Kala website has a pleasant visual effect and a creative and attractive design. Therefore, attract users and be a stimulus for impulsive purchases.

Due to this issue, it is suggested:

- Create a pleasant atmosphere to maintain and attract users.

- Using images and animations to introduce products and services and how to use them to enhance the creative aspect of the website.

- In designing the website, use background colour, text colour and font appropriate to the type of activity, and moving images to direct the eye to the direction that is the retailer's goal.

\section{Conclusion and discussion}

It can be said that expressing the result of each research is a summary of all the actions that have been done during the research, and its results have been stated. Therefore, the results of each research can be used as a guide for its readers. Thus, with the help of the contents of the investigation and practical measures based on the research results to improve online store sites. Also, examine the better understanding of online consumer behaviour from marketers, managers, and web admins of online stores. Analysis of research findings is an integral part of any research. With the correct conclusions and appropriate suggestions related to research, theories can be turned into action. In this chapter, the researcher, based on the collected data and statistical tests, expresses the research results and offers suggestions for marketers, web admins, and designers of online store websites and tips for future research will pay. With the correct conclusions and appropriate recommendations related to research, theories can be turned into action. The following section offers suggestions for marketers, web admins, online store website designers, and directions for future research.

\section{Suggestions and limitations}

- This study has been studied among the citizens of Arak, who have made a sudden purchase from Digi Kala. However, it can also be studied in other communities, such as companies, organizations, and online shoppers.

- The research has investigated the effect of e-shop website features on online shopping behaviour. In future research, we can examine impulsive purchases on e-commerce sites with other services business models.

- Since the quality of e-shop service affects the purchase, It is better for managers, businesses, or other external stakeholders to enhance the quality of websites by providing proper support such as better service and guarantee. Business owners can also attract consumers' trust by delivering quality products at reasonable prices, not delaying sending the requested goods, following up and handling their customers' complaints, and returning defective products. They also can attract more and more 
consumers by investing in website design to be appealing and eye-catching from consumers' perspectives.

Every research in the course of implementation, from design to implementation, faces limitations that will vary depending on the subject, data collection method, and other dimensions of the research. Limitations are like research. This research is not immune to limitations and shortcomings. Some of the most important of these limitations can be summarized as follows:

- Intrinsic limitations of data collection tools (questionnaire).

- The present study has examined the factors affecting sudden shopping in online commerce, so it is impossible to generalize the results to traditional or offline stores.

\section{Peer-review:}

Externally peer-reviewed

\section{Conflict of interests:}

The author(s) has (have) no conflict of interest to declare.

\section{Grant Support:}

The author(s) declared that this study has received no financial support.

\section{Acknowledgement:}

I want to express my very great appreciation to Dr Ghafari, my research supervisor, for his patient guidance, enthusiastic encouragement and helpful critiques of this research work. Finally, my deep and sincere gratitude to my family for their continuous and unparalleled love, help and support.

\section{Author Contributions:}

Idea/Concept/Design: S.N, Data Collection and/or Processing: S.N. Analysis and/or Interpretation: S.N. Literature Review: S.N., Writing the Article: S.N., Critical Review: P.G.., Approval: P.G.

\section{References}

Amiri, Nazanin (2015). "The Impact of Online Shopping Beliefs on Shopping Behaviour Due to Sudden Consumer Motivation in Instant Shopping", Master Thesis, University of Guilan.

Beatty, S. E., \& Ferrell, M. E. (1998). Impulse Buying: Modeling Its Precursors.Journal of Retailing, 74(2), 169-191

Britsman, S. \& Sjolander, K. (2011)."Teenage girls aged 13 to 15 and their impulse consumption of clothes". University of Gotten burg.

Childers, T. L., Carr, C. L., Peck, J., \& Carson, S. (2001). Hedonic and utilitarian motivations for online retail shopping behaviour. Journal of retailing, 77 (4), 511-535.

Chin-Hung Liu, National Chin-Yi (2017), KEY FACTORS IN IMPULSE BUYING: EVIDENCE FROM TAIWAN, Global Journal of Business Research Vol. 11, No. 3, pp. 73-86.

Corbitt, B. J., Thanasankit, T., \& Yi, H. (2003). Trust and e-commerce: a study of consumer perceptions. Electronic commerce research and applications, 2(3), 203-215. 
Cox, A.D., Cox, D., Anderson, R., (2005)." Reassessing the pleasures of store shopping". Journal of Business Research 58, 250-259.

Davis, F. D., Bagozzi, R. P., \& Warshaw, P. R. (1989). User acceptance of computer technology: a comparison of two theoretical models. Management science, 35(8), 982-1003.

Delone, W. H., \& McLean, E. R. (2003). The DeLone and McLean model of information systems success: a ten-year update. Journal of management information systems, 19(4), 9-30.

Dholakia, U. M. (2000)." temptation and resistance: An integrated model of consumption impulse formation and enactment",journal of psychology \& marketing, 17 (11), 995-982.

Floh.A , Madlberger M(2013) "The role of atmospheric cues in online impulse-buying behaviour" Journal of Electronic Commerce Research and Applications 12,425-439.

Fogli, D., \& Guida, G. (2015). A practical approach to the assessment of quality in use of corporate web sites. Journal of Systems and Software, 99, 52-65.

Gajendra ,Sharma and Wang, Lijuan , (2015),"The effects of online service quality of e-commerce websites on user satisfaction",The Electronic Library , Vol. 33 Iss 3 pp.

Ghahnavieh, Adeleh (2015). "The effect of useful features of the website on the intention to buy online", Master Thesis, Yazd University, Yazd.

Grégory Bressolles François Durrieu (2007),"The impact of electronic service quality's dimensions on customer satisfaction and buying impulse", JOURNAL OF CUSTOMER BEHAVIOUR, 2007, Vol. 6, No. 1, pp. 37-56.

Haghighi, m; Tabein, A. (2008). "Assessing the attractiveness and usability of the website (website) of Iran Petrochemical Trading Company from the perspective of domestic customers in the industrial market." Journal of Business Management, 1 (1), 38-21.

Inman,leigh ,j.jrffrey ,mcalister,wayne d(1990)."promotion signal:proxy a price cut?"the journal of consumer research vol17, no $1,74-81$.

Kim, A.J. Ko, E. (2012) Do Social Media Marketing Activities Enhance Customer Equity? An Empirical Study of Luxury Fashion Brand. Journal of Business Research, 65, 1480-1486.

Liu, C., \& Arnett, K. P. (2000). Exploring the factors associated with Web site success in the context of electronic commerce. Information \& management, 38(1), 23-33.

McKinney , V , Kanghyun,Y,\& Zahedi, F.(2002). "The Measurement of Web-Customer Satisfaction: An Expectation and Disconfirmation Approach". Information Systems ResearchVol. 13, No. 3,227-359.

Moe, W. W., \& Fader, P. S. (2004). Capturing Evolving Visit Behaviour in Clickstream Data. Journal of Interactive Marketing, 18 (1), 5-19. http://dx.doi.org/10.1002/dir.10074.

Nielsen, J. (1994).Usability engineering. Boston, MA: AP Professional.

Poddar A, Donthu N,Wei y (2009). " website customer orientations, website quality, and purchase intionations: the role of website personality". Journal of Business RESEARCH, 62, PP. 441-450.

Ponte, E. B., Carvajal-Trujillo, E., \& Escobar-Rodríguez, T. (2015). Influence of trust and perceived value on the intention to purchase.

Rook, D.W. and Hoch, S.J. (1985)." Consuming impulses. Advances in Consumer Research", 12: 23-27.

Song, J., \& Zahedi, F. M. (2005). A theoretical approach to web design in e-commerce: a belief reinforcement model. Management science, 51(8), 1219-1235.

Toufaily, E., Ricard, L., \& Perrien, J. (2013). Customer loyalty to a commercial website: Descriptive meta-analysis of the empirical literature and proposal of an integrative model. Journal of Business Research, 66(9), 1436-1447.

Tsai,W. H. S., \& Men, L. R. (2013)." Motivations and antecedents of consumer engagementwith brand pages on social networking sites". Journal of Interactive Advertising, 13(2),76-87. 
Turban, E., King, D., Lee J., and Vieland, D. (2004), " Electronic Commerce: A managerial perspective", Pearson Prentice Hall, New Jersey.

Universit of Michigan (2019). HOW ONLINE STORES TRICK YOU INTO IMPULSE BUYING. https://www.futurity.org/impulse-buying2047282/\#: :text=The\%20team\%20found\%20that\%20the,products\%2C\%20electronics\%2C\%20and\% 20shoes.

Verhagen, T.Van Dolen, W. (2011). "The influence of online store bliefs on consumer online impulse buying: A model and empirical application". Information \& Management. 48, 320-327.

Yaghoubi, Afsaneh. (2015), "Study of the effect of usability and perceived reputation on website loyalty with emphasis on the level of familiarity of people", Master Thesis, Ardakan University of Art and Architecture

Yang, Z., Cai, S., Zhou, Z., \& Zhou, N. (2005)." Development and validation of an instrument to measure user perceived service quality of information presenting web portals". Information \& Management, 42(4), 575-589.

Zeithaml, V. A., Parasuraman, A., \& Malhotra, A. (2002). "Service quality delivery through web sites: a critical review of extant knowledge". Journal of the academy of marketing science, 30(4), 362-375. 